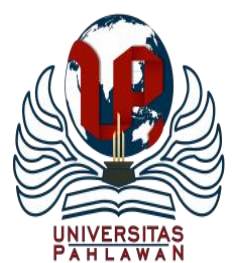

Jurnal Abdidas Volume 2 Nomor 3 Tahun 2021 Halaman 581-596

JURNAL ABDIDAS

http://abdidas.org/index.php/abdidas

\title{
Sistem Informasi Aplikasi Pendataan (SIAP) UMKM Berbasis Kecamatan di Provinsi Kepulauan Bangka Belitung
}

\author{
Hilyah Magdalena $^{1 \bowtie}$, Hadi Santoso $^{2}$, Ade Septryanti ${ }^{3}$ \\ Sistem Informasi, Institut Sains dan Bisnis Atma Luhur, Bangka Belitung, Indonesia ${ }^{1,2}$ \\ Teknik Informatika, Institut Sains dan Bisnis Atma Luhur, Bangka Belitung, Indonesia ${ }^{3}$ \\ E-mail : hilyah@atmaluhur.ac.id ${ }^{1}$, hadisantoso@ atmaluhur.ac.id ${ }^{2}$, adeseptryanti@ atmaluhur.ac.id $^{3}$
}

\begin{abstract}
Abstrak
Kegiatan pengabdian masyarakat ini berlatar belakang adanya kebutuhan mendata ulang Usaha Mikro Kecil Menengah (UMKM) yang masih bertahan selama masa pandemi Covid-19. Hal ini mendorong Dinas Koperasi dan UMKM Provinsi Kepulauan Bangka Belitung bekerja sama dengan dosen-dosen dari Institut Sains dan Bisnis Atma Luhur untuk membangun sistem pendataan UMKM berbasis kecamatan. Metode prototyping adalah metode yang dipilih untuk mengembangkan sistem informasi aplikasi pendataan UMKM ini. Sedangkan metode kegiatan pengabdian masyarakat dilakukan dalam beberapa tahap, yaitu tahap focus group discussion survey data UMKM berdasarkan nama dan alamat, kemudian mempresentasikan prototype aplikasi pendataan UMKM berdasarkan nama dan alamat berbasis web, lalu tahap Webinar Bimtek sebagai bentuk sosialisasi dan pelatihan operator kecamatan. Hasil dari kegiatan pengabdian masyarakat ini adalah Sistem Informasi Aplikasi Pendataan (SIAP) UMKM berbasis kecamatan. Aplikasi ini mampu mendata pelaku UMKM lengkap dengan nama dan lokasi usaha yang di deteksi dengan sistem informasi geografis. Kegiatan mendata ulang UMKM ini agar Dinas Koperasi dan UMKM Bangka Belitung mempunyai data UMKM yang akurat yang dapat mempermudah akses bantuan dari Pemerintah kepada pelaku usaha UMKM. Pemanfaatan sistem informasi aplikasi pendataan UMKM ini diharapkan mampu mendorong perubahan perilaku bisnis UMKM di Bangka Belitung dari yang berbisnis secara konvensional beralih menjadi berbisnis di platform digital.
\end{abstract}

Kata kunci: digitalisasi UMKM, pendataan, Covid-19, Bangka Belitung

\begin{abstract}
This community service activity is motivated by the need to re-register Micro, Small and Medium Enterprises (MSMEs) that still survive during the COVID-19 pandemic. This prompted the Department of Cooperatives and SMEs of the Bangka Belitung Islands Province to work together with lecturers from the Institute of Science and Business Atma Luhur to develop a sub-district-based MSME data collection system. The prototyping method is the method chosen to develop this MSME data collection application information system. While the method of community service activities is carried out in several stages, namely the focus group discussion survey of MSME Data based on names and addresses, then presenting a prototype application for data collection of MSMEs based on web-based names and addresses, then the technical guidance Webinar stage as a form of socialization and training for sub-district operators. The result of this community service activity is a sub-district-based MSME Data Collection Application Information System (SIAP). This application is able to record MSME actors complete with their names and business locations detected by the geographic information system. This activity is to re-register MSMEs so that the Bangka Belitung Cooperatives and MSMEs Office has accurate MSME data that can facilitate access to assistance from the Government for MSME business actors. The utilization of the MSME data collection application information system is expected to be able to encourage changes in MSME business behavior in Bangka Belitung from those who do business conventionally to do business on digital platforms.
\end{abstract}

Keywords: digitizing MSMEs, data collection, Covid-19, Bangka Belitung

Copyright (c) 2021 Hilyah Magdalena, Hadi Santoso, Ade Septryanti

$\triangle$ Corresponding author

Address : Institut Sains dan Bisnis Atma Luhur

Email : hilyah@atmaluhur.ac.id

DOI : $\quad$ https://doi.org/10.31004/abdidas.v2i3.328

ISSN 2721- 9224 (Media Cetak)

ISSN 2721- 9216 (Media Online)

Jurnal Abdidas Vol 2 No 3 Tahun 2021 p-ISSN 2721-9224 e-ISSN 2721-9216 
582 Sistem Informasi Aplikasi Pendataan (SIAP) UMKM Berbasis Kecamatan di Provinsi Kepulauan Bangka Belitung- Hilyah Magdalena, Hadi Santoso, Ade Septryanti

DOI: https://doi.org/10.31004/abdidas.v2i3.328

\section{PENDAHULUAN}

Kondisi dunia saat ini yang sedang dilanda pandemi Covid-19 mempengaruhi semua aspek kehidupan. Banyak cara hidup yang harus berubah dengan adanya pandemi ini, salah satunya adalah cara bertransaksi bisnis. Pelaku UMKM adalah salah satu pelaku bisnis yang terimbas dengan adanya pademi ini. Perilaku baru yang mengurangi kontak dan jaga jarak telah mengubah cara bertransaksi dari transaksi manual ke transaksi digital. Pelaku UMKM harus ikut berubah agar dapat menyesuaikan diri dengan pola transaksi digital. Pelaku UMKM didorong untuk segera beralih ke transaksi digital. Perubahan pola transaksi menjadi berbasis digital juga membantu memperluas pemasaran produk UMKM (Dinas Kominfo 2020).

Desakan kondisi pandemi Covid-19 ternyata mempercepat digitalisasi UMKM yang akan membantu memperluas pasar produk UMKM ke manca negara. Namun demikian upaya untuk mendorong UMKM menjadi UMKM berbasis digital harus melalui tahap sosialisasi kepada pelaku UMKM. Perubahan cara bertransaksi dari manual ke digital membutuhkan strategi pemasaran berbasis digital. Pelaku UMKM harus dibekali ilmu tentang cara mempromosikan produk agar manarik dan mampu bersaing dengan produk serupa. Berdasarkan kondisi tersebut, maka langkah pertama untuk mendorong digitalisasi UMKM adalah melakukan pendataan UMKM secara akurat. Mengingat kondisi saat ini yang masih tinggi tingkat penyerabaran virus Covid-19, maka teknis pendataan UMKM dilakukan per kecamatan. Pendataan UMKM per kecamatan dilakukan berbasis web. Pelaku UMKM diminta untuk memperbarui data diri dan data usahanya saat ini. Data UMKM yang terkumpul di lecamatan selanjutnya akan dikumpulkan di provinsi khususnya di Dinas Koperasi dan UMKM Provinsi Kepulauan Bangka Belitung (Rahimah Dinas Kominfo 2020).

Pemerintahan Provinsi mendukung kegiatan bimbingan teknis pendataan UMKM By Name By Address berbasis kecamatan di Bangka Belitung. Hal ini sebagai implementasi dari Peraturan Presiden No. 39 Tahun 2019. Implementasi Peraturan Presiden No. 39 Tahun 2019 tentang Satu Data Indonesia bertujuan untuk mewujudkan keterpaduan, perencanaan, pelaksanaan, evaluasi, dan pengendalian pembangunan yang perlu didukung dengan data yang akurat, terpadu, dan mudah diakses (Babel Hits 2020).

Tuntutan untuk menyesuaikan diri dengan tuntutan harus mendigitalisasi UMKM di Bangka Belitung terus didorong oleh Pemerintah Provinsi Bangka Belitung. Produk-produk khas Bangka Belitung yang beragam dapat dijual ke market place dan mampu menjangkau pangsa pasar yang lebih luas. Sejatinya sudah cukup banyak UMKM di Bangka Belitung yang telah memanfaatkan sosial media untuk menjual produknya. Namun sosial media yang dimanfaatkan belum sepenuhnya maksimal mendukung penjualan produk. Pelaku UMKM sudah memasarkan produknya secara online. Pada saat pandemi, UMKM yang sudah memasarkan produk secara digital lebih mampu beradaptasi. Untuk membuat pelaku UMKM lebih berdaya dalam menjual produknya, maka Pemerintah Provinsi melakukan 
583 Sistem Informasi Aplikasi Pendataan (SIAP) UMKM Berbasis Kecamatan di Provinsi Kepulauan Bangka Belitung- Hilyah Magdalena, Hadi Santoso, Ade Septryanti

DOI: https://doi.org/10.31004/abdidas.v2i3.328

beberapa usaha seperti kerjasama dengan beberapa market place nasional. UMKM dibimbing untuk membuat akun market place dan menampilkan foto produk sebagai etalase toko digital yang mereka miliki. Ini agar pelaku UMKM terbiasa melakukan berjualan di market place (Ramdhani 2020).

Pada saat mendata UMKM di Provinsi Bangka Belitung, data yang saat ini dimiliki oleh dinas UMKM belum sepenuhnya diperbarui. Sulitnya mendapatkan data pelaku UMKM yang terbaru karena beberapa kendala seperti, tempat usaha yang pindah tempat, nama usaha yang berubah, jenis usaha yang berubah. Kendala ini menjadikan upaya pembinaan UMKM menjadi kurang tepat sasaran. Berdasarkan kondisi tersebut, maka langkah pertama untuk mendorong digitalisasi UMKM adalah melakukan pendataan UMKM secara akurat. Mengingat kondisi saat ini yang masih tinggi tingkat penyebaran virus Covid19, maka teknis pendataan UMKM dilakukan per kecamatan. Pendataan UMKM per kecamatan dilakukan berbasis web. Pelaku UMKM diminta untuk memperbarui data diri dan data usahanya saat ini. Data UMKM yang terkumpul di kecamatan selanjutnya akan dikumpulkan di provinsi khususnya di Dinas Koperasi dan UMKM Provinsi Kepulauan Bangka Belitung (Kominfo 2020).

Pendataan UMKM By Name By Address sekecamatan di wilayah Provinsi Kepulauan Bangka Belitung adalah salah satu bentuk implementasi dari Peraturan Presiden Republik Indonesia No 39 Tahun 2019 tentang Satu Data Indonesia (Kemenkumham RI 2019).
Mengingat desain sistem adalah berbasis web, maka prinsip desain web, adalah seluruh proses pembuatan situs web, dari awal hingga akhir, baik itu menggunakan HTML, CSS, dan desain visual web. Prinsip membuat situs web yang dapat diakses yang memungkinkan pengguna dengan mudah dan cepat dalam menavigasi informasi, apa pun jenis browser, kecepatan koneksi, atau perangkat penjelajahan. Prinsip desain web yang baik adalah desain web yang responsif, metode baru dalam mendesain situs web yang beradaptasi dengan perangkat mulai dari ponsel hingga monitor desktop. Desain web dapat dibuat dari awal atau mendesain ulang situs yang ada, akan membantu pemilik situs web dalam menyampaikan konten web dengan cara yang lebih responsif, mudah diakses, dan menarik secara visual (Joel Sklar 2015).

Pengembangan sistem berbasis web untuk mendukung kemajuan usaha UMKM juga dilakukan pada beberapa daerah. Berikut ini adalah beberapa penelitian lain yang serupa yang pernah dilakukan sebelumnya. Penelitian yang dilakukan untuk UMKM Batik Rindani di Jambi yang membangun sistem berbasis web untuk membantu kegiatan penjualan dan promosi produk. Salah satunya adalah fasilitas penting yang bisa dimanfaatkan oleh pelanggan yaitu berupa fiturfitur forum diskusi, list data produk, penginputan data, informasi produk yang tersedia (Dedy Setiawan dan Lutfi 2018).

Penelitian selanjutnya adalah pemetaan lokasi pelaku UMKM di Kabupaten Kudus. Pemetaan Industri Kecil dan Menengah (IKM) menggunakan Sistem Informasi Geografis (SIG) 
584 Sistem Informasi Aplikasi Pendataan (SIAP) UMKM Berbasis Kecamatan di Provinsi Kepulauan Bangka Belitung- Hilyah Magdalena, Hadi Santoso, Ade Septryanti

DOI: https://doi.org/10.31004/abdidas.v2i3.328

berbasis web di Kabupaten Kudus merupakan solusi dari keberadaan industri kecil yang ada. Pemetaan ini bertujuan untuk membantu mempermudah pegawai Dinas Perindustrian Koperasi dan UMKM di Kabupaten Kudus dalam mengelola data Industri Kecil dan Menengah (IKM) serta memberikan tempat bagi pemilik IKM untuk ikut berpartisipasi dalam persaingan industri dan memberikan informasi kepada masyarakat tentang apa saja IKM yang ada di Kabupaten Kudus secara up to date dalam satu website. Dari sistem ini menghasilkan tampilan informasi dari masing-masing IKM secara detail mulai dari gambaran IKM, produk yang dimiliki, hingga tambahan fitur foto produk atau tempat IKM dan peta lokasi geografis IKM dari Google Maps. Sistem ini merupakan pengembangan konsep pendataan Industri Kecil dan Menengah (IKM) yang ada di Dinas Perindustrian Koperasi dan UMKM Kabupaten Kudus (Wulandari, Prasetyo Utomo, and Nugraha 2016).

Penelitian serupa juga dilakukan di Dinas UMKM Labuhan Batu. Pengembangan sistem pendataan UMKM berbasis web. Dengan adanya sistem informasi yang dirancang maka pengolahan data UMKM lebih teroptimasi, baik dari segi penggunaan maupun penyimpanan datanya (arsip), sehingga proses manjemen data dapat informasi lebih efektif dan efesiensi sehingga menghasilkan output yang lebih cepat dan akurat. Sistem yang dirancang sudah efisien dalam mendata dan dilengkapi (Purba, Karim, and Trianovie 2019).

Pendataan UMKM berbasis web juga dilakukan di Dinas UMKM Kota Magelang. Penelitian tersebut merancang dan membangun sistem informasi UMKM di bawah binaan Diskoperindag berbasis web di Kota Magelang yang dapat diakses Diskoperindag dan seluruh masyarakat. Masyarakat dapat mengetahui informasi, perkembangan serta lokasi UMKM yang berada di bawah binaan Diskoperindag Kota Magelang (Nurcholik, S, and Susilo n.d.).

Pengabdian masyarakat ini bermanfaat untuk pelaku UMKM di Provinsi Bangka Belitung, juga bermanfaat untuk Dinas Koperasi UMKM agar dapat mengetahui kondisi dan posisi UMKM yang saat ini ada di Provinsi Bangka Belitung. Data UMKM yang akurat memudahkan Pemerintah Provinsi Bangka Belitung untuk melakukann pembinaan dan peningkatan kualitas UMKM.

Pengabdian masyarakat ini bertujuan untuk mengembangkan sistem berbasis web di Dinas Koperasi dan UMKM Provinsi Bangka Belitung yang mampu mendata UMKM berdasarkan nama dan alamat yang presisi berdasarkan koordinat. Pendataan UMKM ini dilakukan terorganisir dari level kecamatan. Hasil pendataan UMKM berdasarkan nama dan alamat dari masing-masing kecamatan yang ada di Provinsi Bangka Belitung, kemudian dikumpulkan di Dinas Koperasi dan UMKM Provinsi Bangka Belitung.

\section{METODE}

Pelaksanaan kegiatan pengabdian masyarakat ini dilakukan oleh tim dosen dari Institut Sains dan Bisnis Atma Luhur. Mengingat skala pendataan UMKM yang cukup banyak dan tersebar pada beberapa kecamatan di Provinsi Kepulauan Bangka Belitung, maka kegiatan 
585 Sistem Informasi Aplikasi Pendataan (SIAP) UMKM Berbasis Kecamatan di Provinsi Kepulauan Bangka Belitung- Hilyah Magdalena, Hadi Santoso, Ade Septryanti

DOI: https://doi.org/10.31004/abdidas.v2i3.328

Pengabdian Masyarakat ini dilakukan dalam tiga tahap yang berkesinambungan.

1. Tahap pertama dalam kegiatan Abdimas ini adalah focus group discussion survei data UMKM berdasarkan nama dan alamat di Kantor Dinas Koperasi dan UMKM Propinsi Kepulauan Bangka Belitung. Hasil survei menjadi dasar tim dosen untuk menganalisa dan mendesain sistem pendataan UMKM berbasis web.

2. Setelah aplikasi pendataan selesai dirancang, maka tahap kedua adalah melakukan presentasi prototype aplikasi pendataan UMKM berdasarkan nama dan alamat berbasis web di Bangka Belitung.

3. Tahap ketiga adalah melakukan webinar Bimtek Pendataan UMKM By Name By Address berbasis kecamatan se-Provinsi Bangka Belitng sebagai bentuk sosialisasi dan pelatihan tahap pertama bagi para operator UMKM di kecamatan.

4. Tahap keempat adalah evaluasi kegiatan pengabdian masyarakat. Evaluasi dilakukan dalam bentuk focus group discussion antara tim dosen dari Institut Sains dan Bisnis Atma Luhur dan operator kecamatan. Masukan dari operator saat mendata UMKM di wilayah kecamatan masingmasing menjadi catatan bagi Dinas Koperasi dan UMKM jika memerlukan pengembangan sistem lebih lanjut.

5. Pembuatan laporan dan dokumentasi kegiatan.

Secara teknis kegiatan pengabdian kepada masyarakat telah berlangsung dengan lancar.
Sesuai dengan jadwal pelaksanaan yang telah disepakati bersama, maka kegiatan PKM ini dilaksanakan pada tanggal 15 September sampai 4 Desember 2020 di Kantor Dinas Koperasi dan UMKM Provinsi Kepulauan Bangka Belitung.

\section{HASIL DAN PEMBAHASAN}

Hasil pengabdian ini adalah aplikasi pendataan UMKM By Name By Address berbasis web di Provinsi Kepulauan Bangka Belitung. Berikut ini adalah tangkapan layar aplikasi pendataan tersebut. Pengembangan sistem berbasis web ini mengacu analisa dan desain sistem metode prototyping (Dennis, Wixom, and Tegarden 2012).

\section{Halaman Muka}

\section{a. Halaman home}

Website UMKM merupakan sebuah sistem yang memiliki tujuan utama pemetaan industri rumahan di Kawasan Provinsi Kepulauan Bangka Belitung. Melalui website ini, masyarakat dapat mencari informasi terkait dengan peta persebaran usaha mikro, kecil dan menengah sesuai dengan kategorinya.

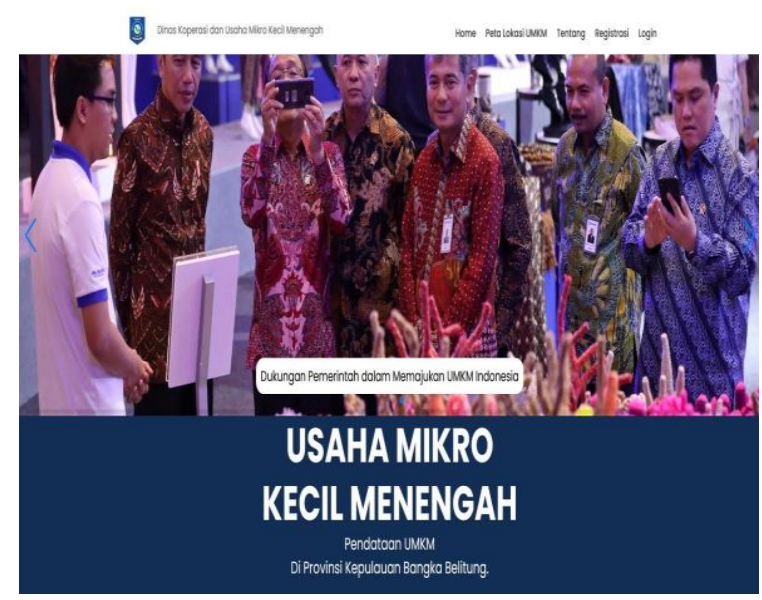

Gambar 1. Tampilan Muka 
586 Sistem Informasi Aplikasi Pendataan (SIAP) UMKM Berbasis Kecamatan di Provinsi Kepulauan Bangka Belitung- Hilyah Magdalena, Hadi Santoso, Ade Septryanti

DOI: https://doi.org/10.31004/abdidas.v2i3.328

\section{b. Pencarian Data UMKM}

Visitor dapat melakukan pencarian sebaran data UMKM berdasarkan kriteria tertentu. Beberapa parameter yang dapat ditentukan dalam mencari data UMKM adalah sebagai berikut:

1. Nama UMKM, secara spesifik menyebutkan nama UMKM.

2. Kecamatan, kecamatan dimana UMKM tersebut berada.

3. Skala Usaha UMKM, skala usaha atau kategori UMKM.

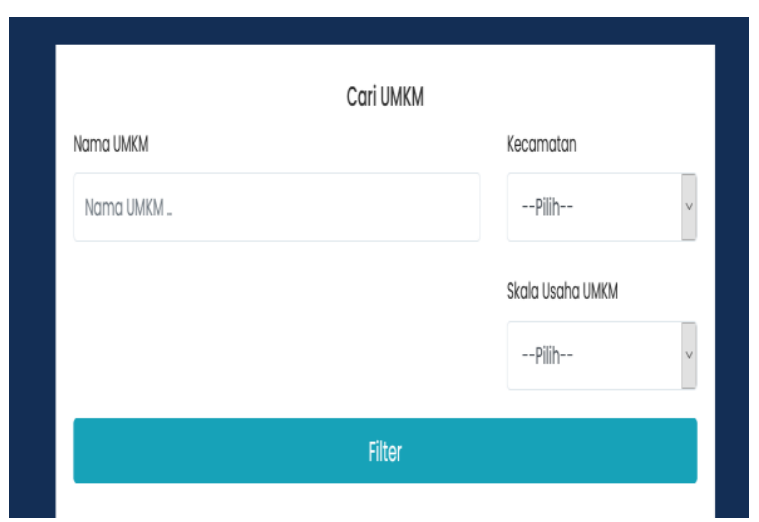

Gambar 2. Pencarian Data UMKM

Gambar 2. di atas menunjukkan contoh pencarian dengan nama "Umah", kecamatan yang dipilih adalah "Gerunggang" dan jenis industrinya adalah "Pemula". Setelah visitor tetapkan parameter tersebut pada form pencarian data UMKM, maka selanjutnya visitor akan diarahkan ke tampilan berikut:

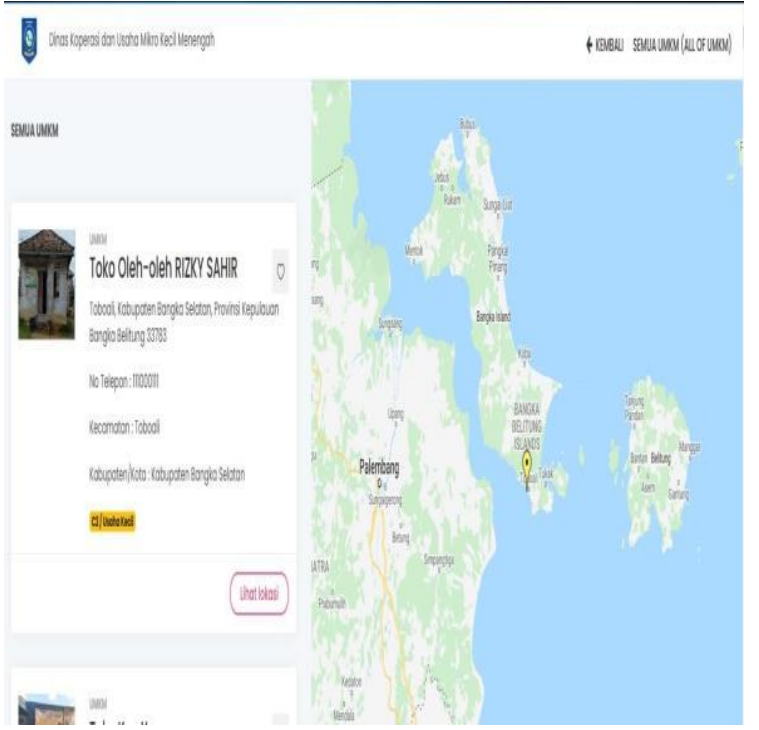

Gambar 3. Pencarian Data UMKM

Pada bagian sidebar kiri pada Gambar 3 di atas terdapat daftar informasi UMKM yang berisi nama UMKM, alamat, nomor telepon, kecamatan, kabupaten/kota dan skala usaha yang sesuai dengan yang difilter, sedangkan pada sisi kanan adalah lokasinya pada peta. Klik pada tombol lihat lokasi untuk mengarahkan tampilan peta ke lokasi (klik icon kuning pada peta sebelah kanan) UMKM yang dituju.

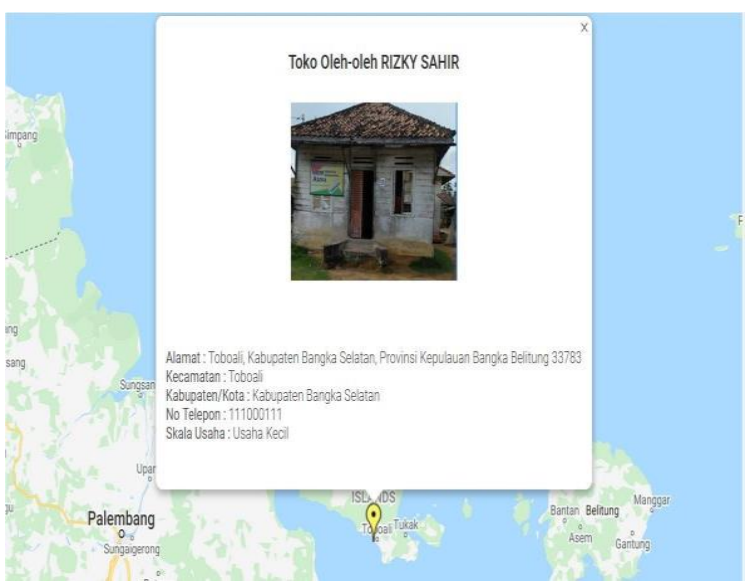

Gambar 4. Detail Pencarian Data UMKM 
587 Sistem Informasi Aplikasi Pendataan (SIAP) UMKM Berbasis Kecamatan di Provinsi Kepulauan Bangka Belitung- Hilyah Magdalena, Hadi Santoso, Ade Septryanti

DOI: https://doi.org/10.31004/abdidas.v2i3.328

Klik pada pin point di peta, sebuah pop up akan muncul yang akan menampilkan detail informasi UMKM terkait. Gambar di atas menunjukkan detail nama, alamat, kecamatan, kabupaten/kota dan skala usahanya.

\section{c. Registrasi}

Cara untuk dapat menjadi bagian dari website UMKM, visitor harus mendaftarkan usahanya melalui fitur Registrasi. Cara untuk registrasi dapat dengan menekan tombol Registrasi di bagian daftar usaha atau di kolom navigasi.

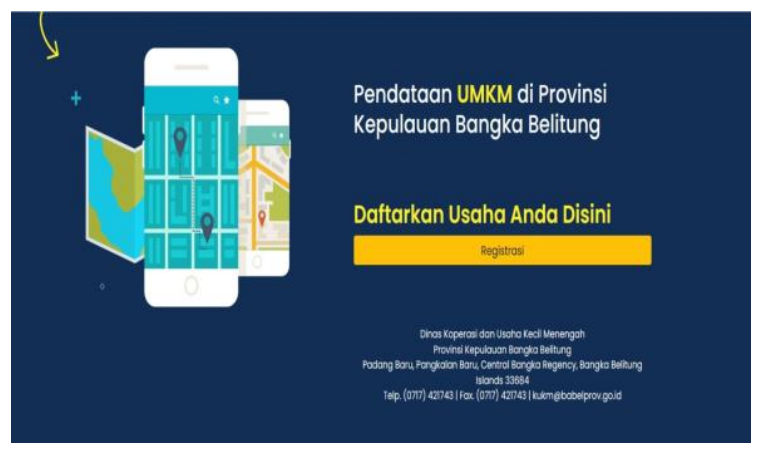

Gambar 4. Detail Pencarian Data UMKM

Setelah menekan tombol registrasi, visitor akan diarahkan ke halaman registrasi. Isi kolom registrasi untuk menambahkan data industri UMKM. Setelah selesai mengisi formulir registrasi, klik tombol simpan. Selanjutnya visitor dapat login ke dalam sistem sebagai seorang user.

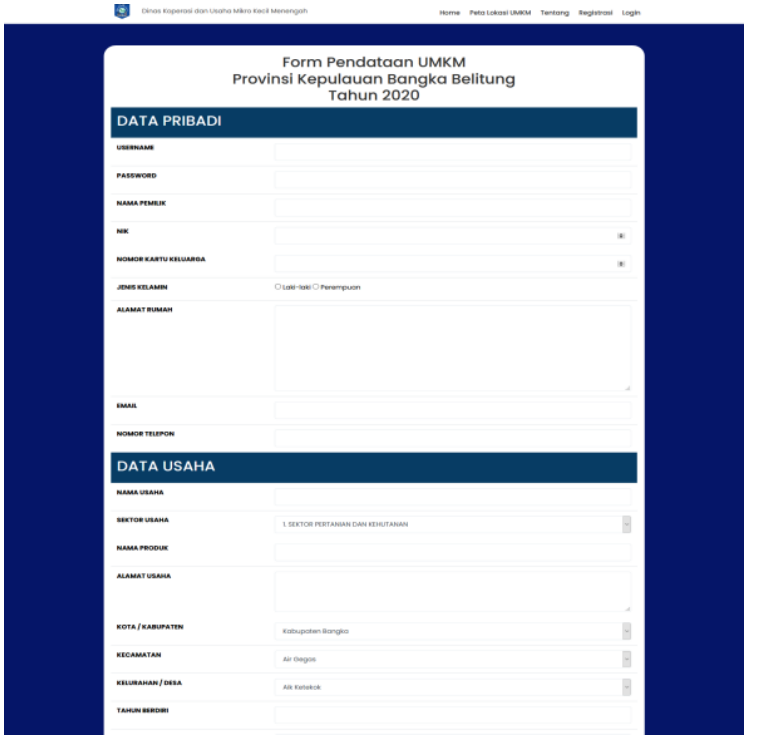

Gambar 6. Formulir Registrasi UMKM

Pada bagian pengisian longitude dan latitude dapat dibantu dengan menggunakan website: https://www.latlong.net/ dengan cara klik pada tulisan di bawah field longitude.

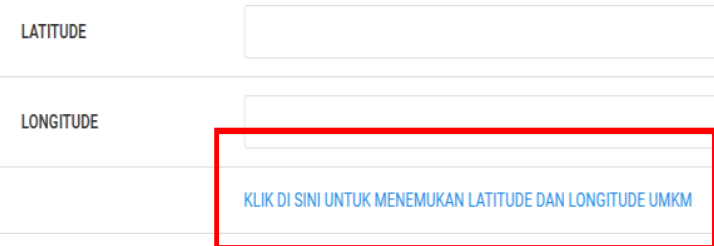

Gambar 7. Pengisian Longitude dan Latitude

Setelah pengunjung masuk ke alamat website tersebut, klik pada peta sesuai dengan lokasi UMKM. Selanjutnya salin (copy paste) angka latitude dan longitude yang muncul pada laman web: latlong.net ke halaman registrasi. 
588 Sistem Informasi Aplikasi Pendataan (SIAP) UMKM Berbasis Kecamatan di Provinsi Kepulauan Bangka Belitung- Hilyah Magdalena, Hadi Santoso, Ade Septryanti

DOI: https://doi.org/10.31004/abdidas.v2i3.328

A LatLong net Gegoraphic Tools Pricing Places TV Series Movies QbatLong 8 User Login

Latitude and Longitude Finder

Latitude and Longitude are the units that represent the coordinates at geographic coordinate system. To make a search,

use the name of a place, city, state, or address, or click the location on the map to find lat long coordinates.

Place Name

Type A Place Name

Add the wunniy code for better resul's. Ex London, UK

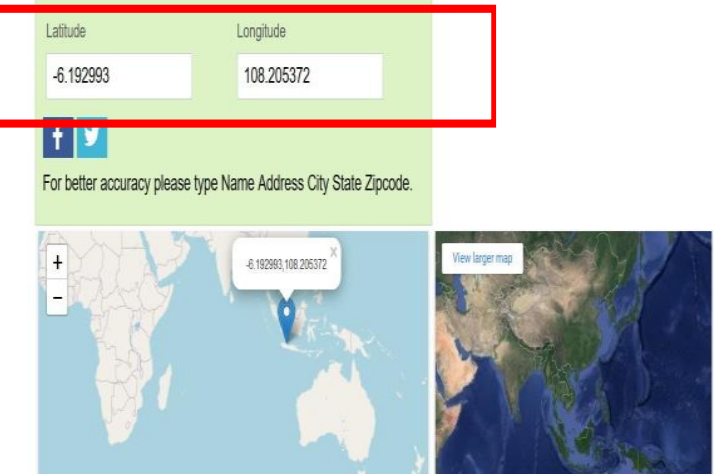

Gambar 8. Detail Cara Pengisian Longitude dan Latitude

Data yang digunakan sebagai Unique Key adalah NIK. Apabila ada data NIK yang kembar dengan database, maka aplikasi akan memberikan notifikasi bahwa data NIK sudah terdaftar.

\section{PEGSPASS GAGQL.}

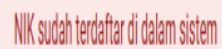

Gambar 9. Informasi Notifikasi NIK

\section{d. Halaman Login}

Member yang telah terdaftar ke dalam sistem merupakan pelaku UMKM. Member dapat masuk ke dalam halaman member untuk melakukan manajemen produk dan perbaikan informasi UMKM. Cara untuk masuk ke halaman member, klik pada tombol login di kolom navigasi. Masukkan username dan password yang telah didaftarkan pada sistem. Jika kombinasi username dan password benar, maka visitor akan masuk ke halaman member. Jika kombinasi username dan password masih salah, maka visitor akan diminta untuk memasukkan kembali username dan password yang benar. Gambar berikut menunjukkan form login dengan kredensial akun yang telah dibuat sebelumnya. Klik login maka Anda akan diarahkan ke halaman member.

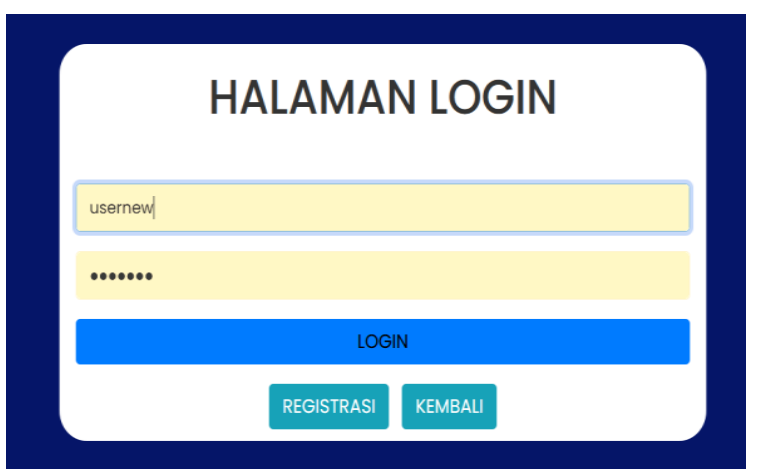

Gambar 10. Halaman Login

\section{Halaman Member}

\section{a. Halaman Member: Dashbord}

Halaman member menggunakan contoh akun "usernew" yang sudah dibuat sebelumnya. Halaman member memiliki tiga bagian utama, yakni dashboard, produk dan update profil. Halaman utama dari halaman member adalah dashboard. Di dalam dashboard terdapat sekilas informasi terkait dengan sistem, jumlah UMKM, kriteria pengelompokan dan jumlah user yang terdaftar. 
589 Sistem Informasi Aplikasi Pendataan (SIAP) UMKM Berbasis Kecamatan di Provinsi Kepulauan Bangka Belitung- Hilyah Magdalena, Hadi Santoso, Ade Septryanti

DOI: https://doi.org/10.31004/abdidas.v2i3.328

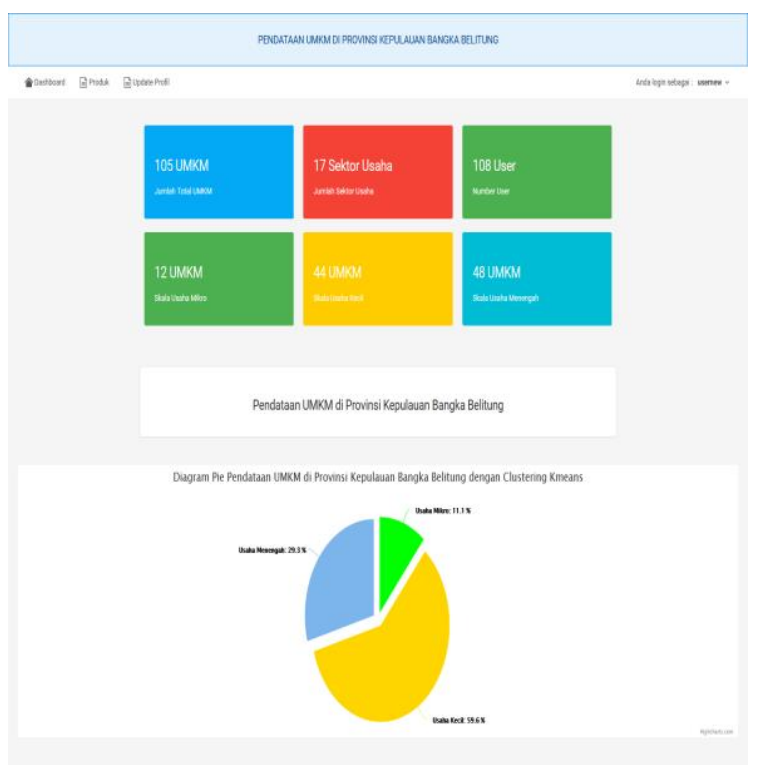

Gambar 11. Halaman Member : Dasboard

\section{b. Halaman Member : Produk}

Halaman produk adalah wadah dimana member dapat menambah, mengedit dan menghapus data produk yang dijual. Cara untuk menambah produk, klik pada tombol tambah (tombol biru), kemudian cara untuk mengedit produk, klik pada tombol obeng (tombol hijau) di kolom opsi. Cara untuk menghapus produk, klik pada tombol tempat sampah (tombol merah).

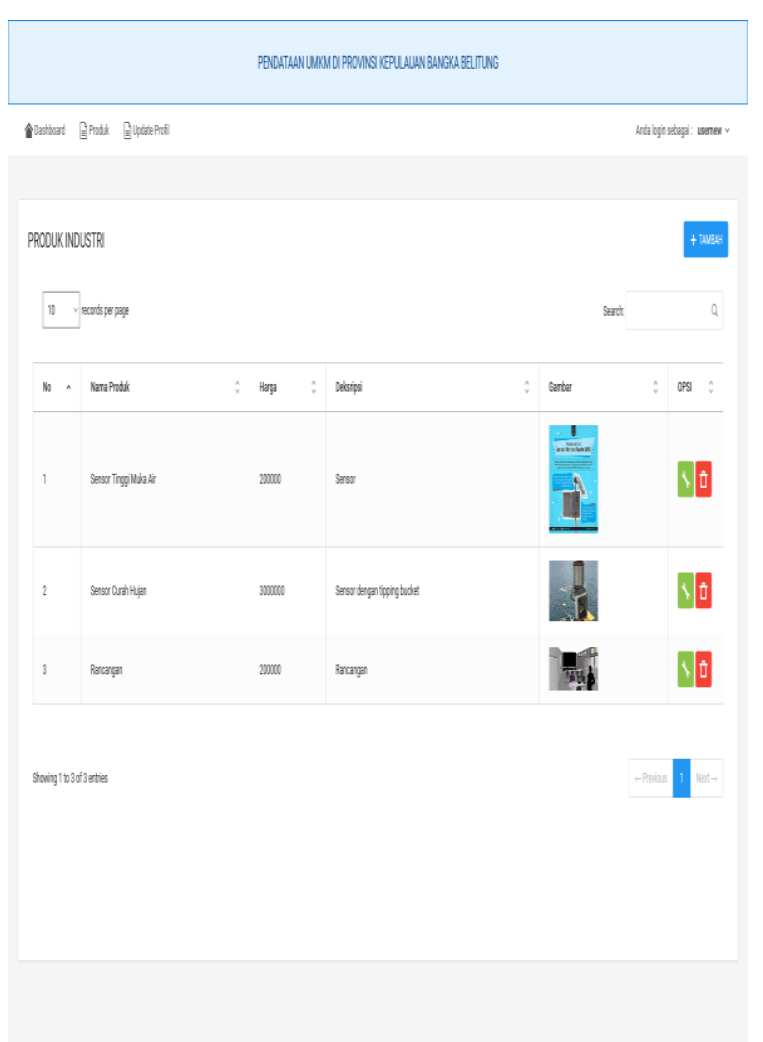

Gambar 12. Halaman Member : Produk

Pada halaman tambah data, member akan disajikan formulir dengan beberapa isian yang harus ditambahkan, yakni nama, harga, keterangan dan foto produk. Jika telah selesai menambah data produk, klik tombol simpan (tombol biru). Gambar berikut menunjukkan contoh penambahan data sensor curah hujan ke dalam data produk. 
590 Sistem Informasi Aplikasi Pendataan (SIAP) UMKM Berbasis Kecamatan di Provinsi Kepulauan Bangka Belitung- Hilyah Magdalena, Hadi Santoso, Ade Septryanti

DOI: https://doi.org/10.31004/abdidas.v2i3.328

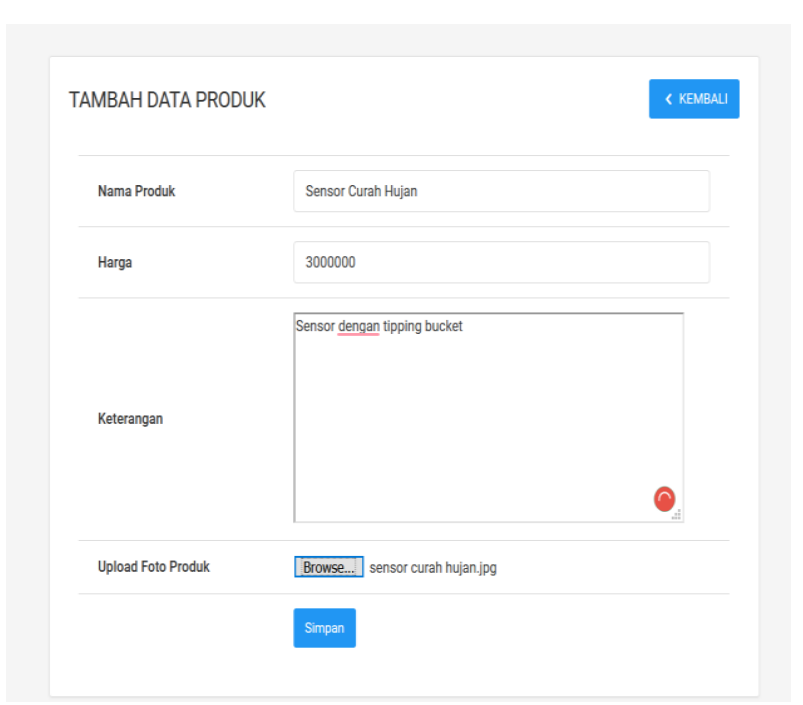

Gambar 13. Halaman Member : Tambah Data Produk

Pada halaman edit data, member akan disajikan formulir dengan beberapa isian yang dapat diperbarui, yakni nama, harga, keterangan dan foto produk. Jika telah selesai mengedit data produk, klik tombol simpan (tombol biru). Gambar 14. menunjukkan contoh edit data "sensor TMA". Ubah Namanya menjadi "Sensor Tinggi Muka Air".

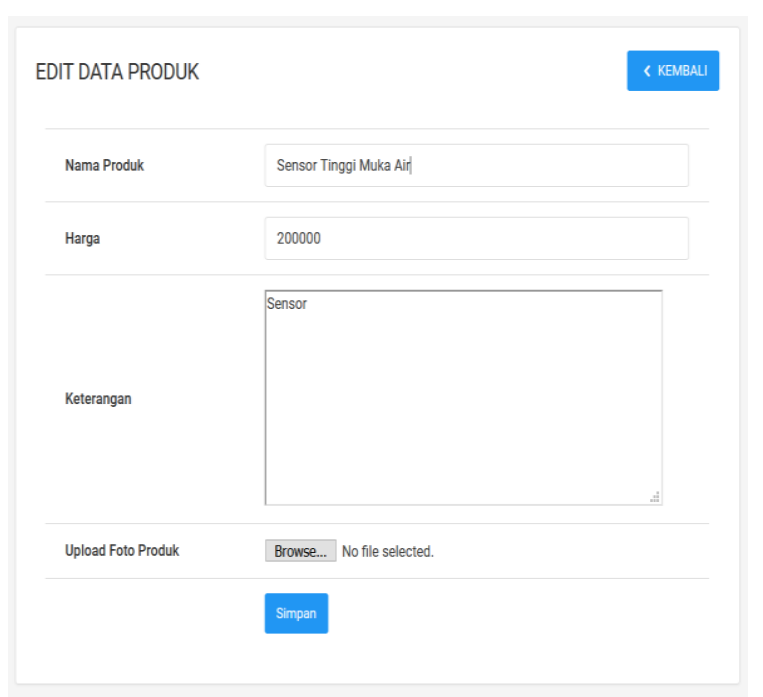

Gambar 14. Halaman Member : Edit Produk

\section{c. Halaman Member : Update Profil}

Pada halaman update profil, member dapat memperbarui profil usaha UMKM mereka. Pada halaman ini, sebuah form berisi data terkini akan muncul. Member dapat memperbarui pada poin tertentu atau seluruh data. Jika telah selesai mengedit, klik tombol simpan (tombol biru). Pada contoh gambar di bawah ini, ada perubahan data pada profil UMKM. Ubah nama industri dari "Keripik Kentang" menjadi "Instrumen Telemetri" dan jenis usaha "makanan" menjadi "elektronika".

\section{EDIT DATA UMKM}

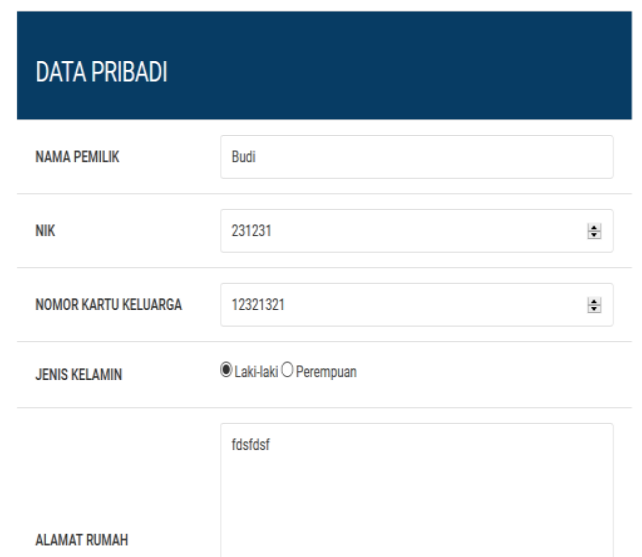

Gambar 15. Halaman Member : Update Profil

\section{d. Halaman Member : Ganti Password}

Cara untuk mengganti password member, klik pada nama di pojok kanan bagian navigasi lalu pilih ganti password. Sebuah halaman untuk mengubah password akan muncul. Selanjutnya member harus memasukkan password baru kemudian tekan simpan jika telah selesai ubah password. 
591 Sistem Informasi Aplikasi Pendataan (SIAP) UMKM Berbasis Kecamatan di Provinsi Kepulauan Bangka Belitung- Hilyah Magdalena, Hadi Santoso, Ade Septryanti

DOI: https://doi.org/10.31004/abdidas.v2i3.328

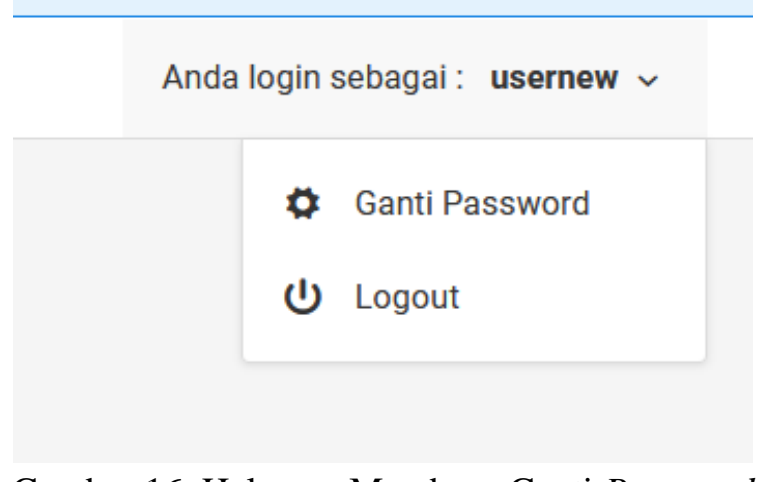

Gambar 16. Halaman Member : Ganti Password
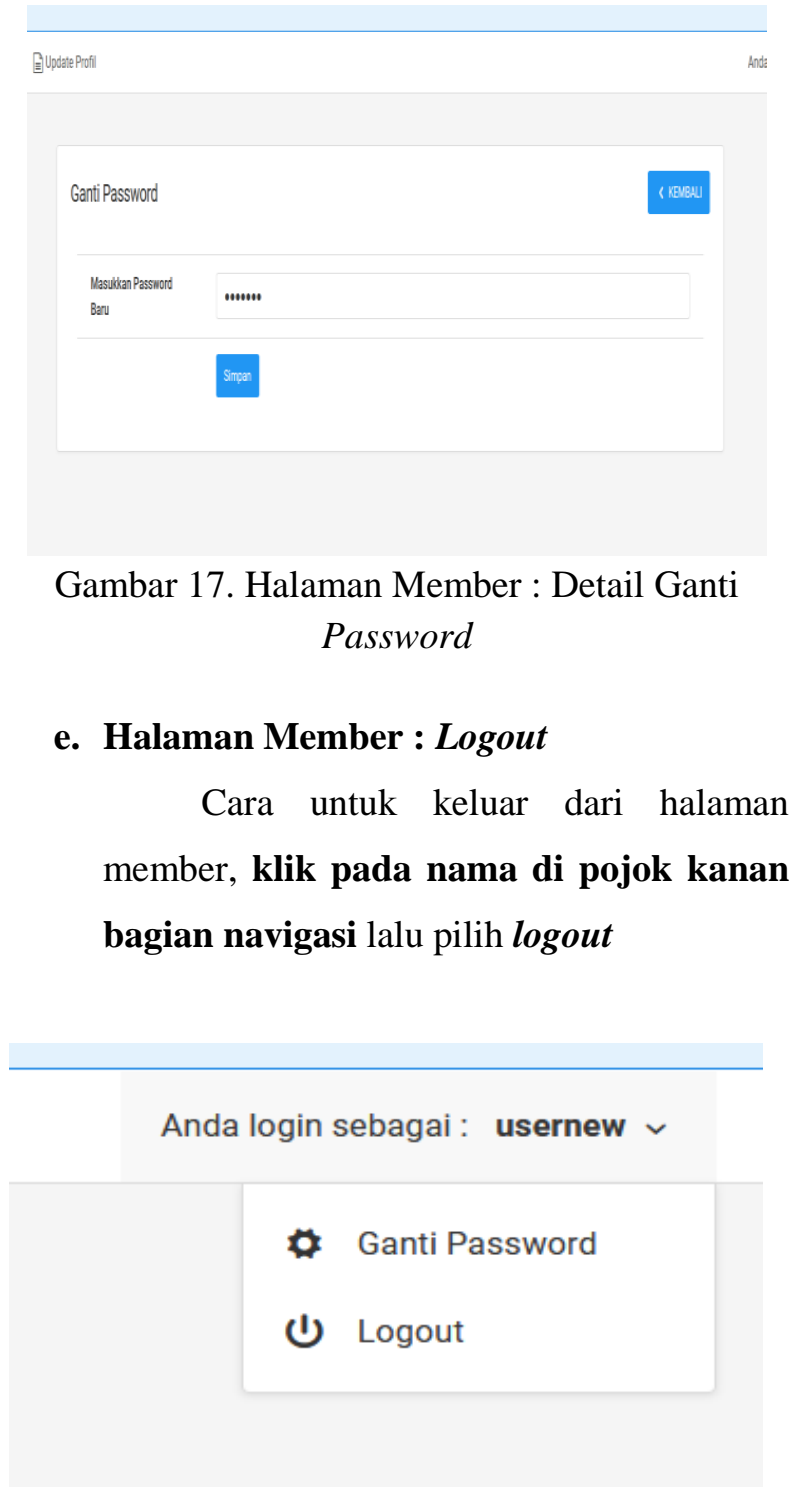

Gambar 18. Halaman Member : Logout

\section{Halaman Admin}

\section{a. Halaman Admin: Dashbord}

Halaman admin memiliki beberapa sub halaman, yakni dashboard, berita, data umkm, cari UMKM, dan akun. Di dalam dashboard terdapat sekilas informasi terkait dengan sistem, jumlah UMKM, sektor usaha yang ada di Provinsi Kepulauan Bangka Belitung dan jumlah user yang terdaftar,

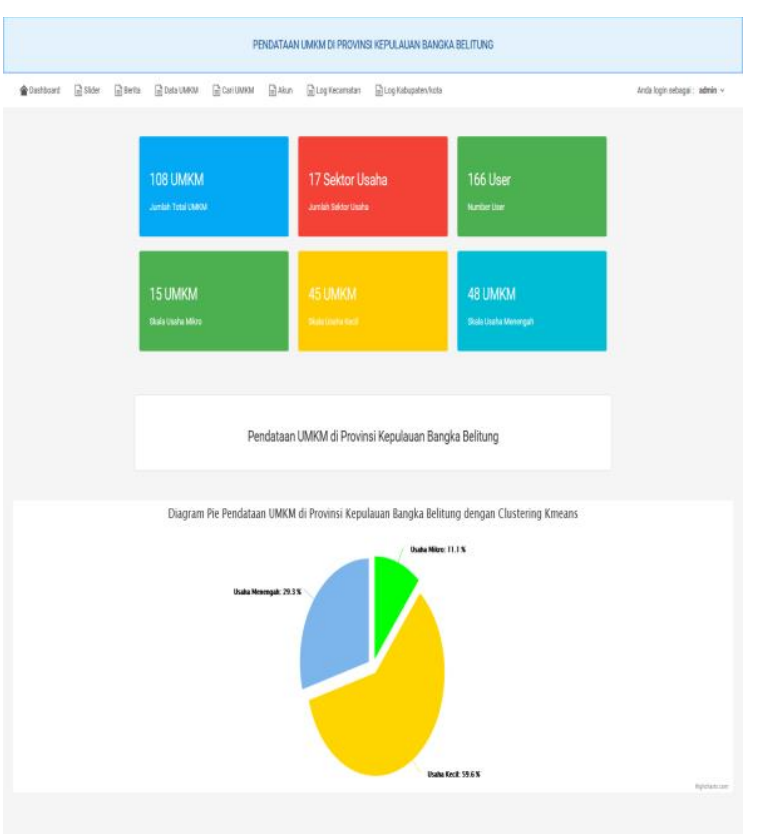

Gambar 19. Halaman Admin : Dashboard

\section{b. Halaman Admin : Slider}

Halaman slider adalah tempat dapat menambah, mengedit dan menghapus data slider, yakni sebuah gambar yang muncul silih berganti pada bagian muka halaman website. Cara untuk menambah slider, klik pada tombol tambah (tombol biru), untuk mengedit slider, klik pada tombol obeng (tombol hijau) di kolom opsi. Cara untuk menghapus slider, klik pada tombol tempat sampah (tombol merah). 
592 Sistem Informasi Aplikasi Pendataan (SIAP) UMKM Berbasis Kecamatan di Provinsi Kepulauan Bangka Belitung- Hilyah Magdalena, Hadi Santoso, Ade Septryanti

DOI: https://doi.org/10.31004/abdidas.v2i3.328

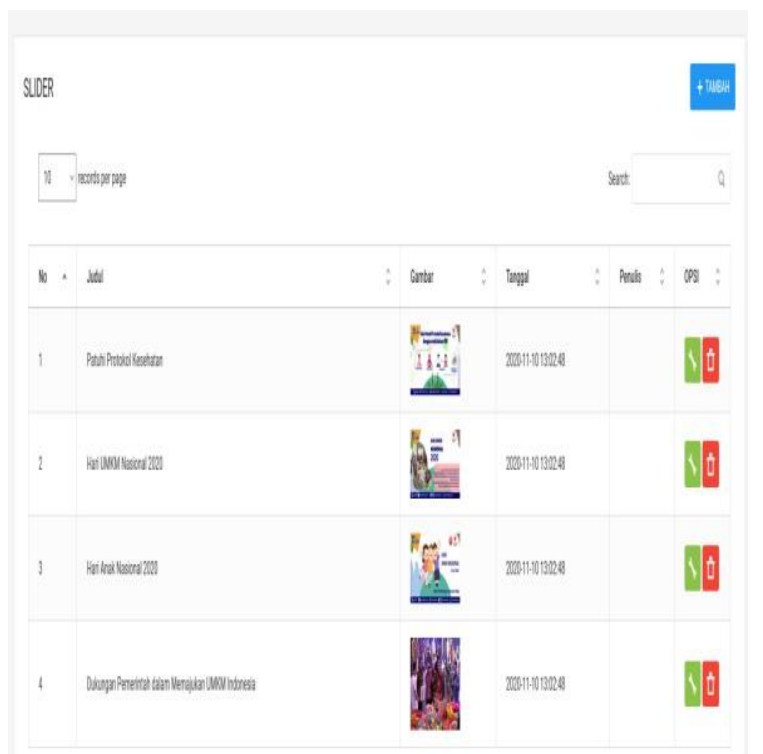

Gambar 20. Halaman Admin : Slider

Pada halaman tambah slider, admin akan disajikan formulir dengan beberapa isian yang harus ditambahkan, yakni judul dan gambar. Jika telah selesai menambah data berita, klik tombol simpan (tombol biru).

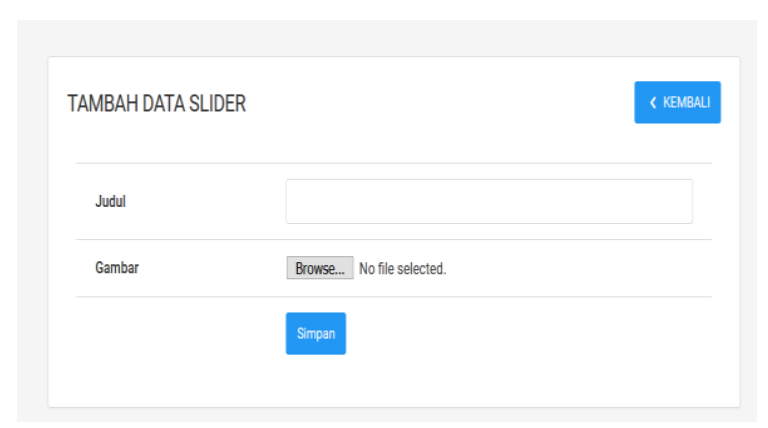

Gambar 21. Halaman Admin : Tambah Data Slider

Pada halaman edit slider, admin akan disajikan formulir dengan beberapa isian yang dapat diperbarui, yakni judul, dan gambar. Jika telah selesai mengedit data slider, klik tombol simpan (tombol biru).

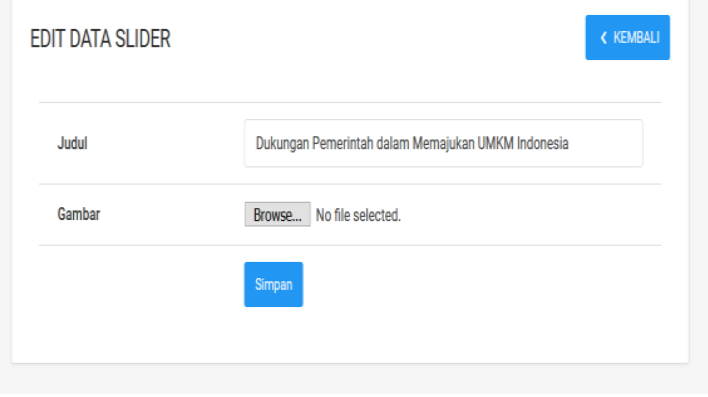

Gambar 22. Halaman Admin : Edit Data Slider

\section{c. Halaman Admin: Berita}

Halaman berita merupakan tempat dimana administrator dapat menambah, mengedit dan menghapus data berita terkait dengan UMKM dan UMKM di Indonesia. Cara untuk menambah berita, klik pada tombol tambah (tombol biru), kemudian cara untuk mengedit berita, klik pada tombol obeng (tombol hijau) di kolom opsi. Selanjutnya, cara untuk menghapus berita, klik pada tombol tempat sampah (tombol merah). 
593 Sistem Informasi Aplikasi Pendataan (SIAP) UMKM Berbasis Kecamatan di Provinsi Kepulauan Bangka Belitung- Hilyah Magdalena, Hadi Santoso, Ade Septryanti

DOI: https://doi.org/10.31004/abdidas.v2i3.328

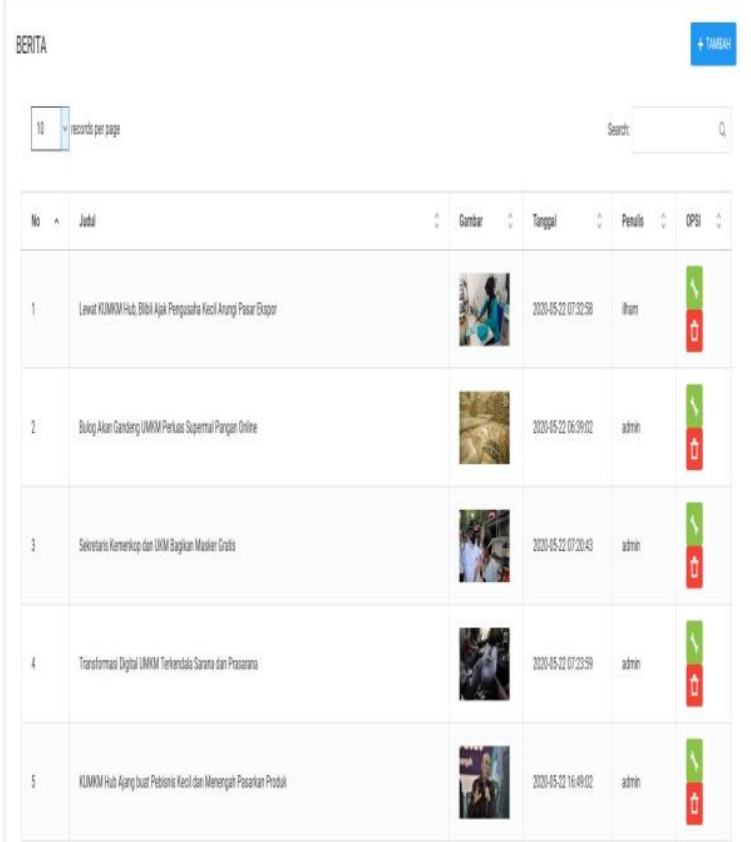

Gambar 23. Halaman Admin: Berita

\section{d. Halaman Admin: Data UMKM}

Halaman data UMKM memuat seluruh usaha UMKM yang telah terdaftar dalam sistem. Administrator dapat menambah, mengedit dan menghapus data terkait dengan UMKM secara independen. Cara untuk menambah data UMKM, klik pada tombol tambah (tombol biru), kemudian cara untuk mengedit UMKM, klik pada tombol obeng (tombol hijau) di kolom opsi. Jika kita ingin menghapus UMKM, klik pada tombol tempat sampah (tombol merah).

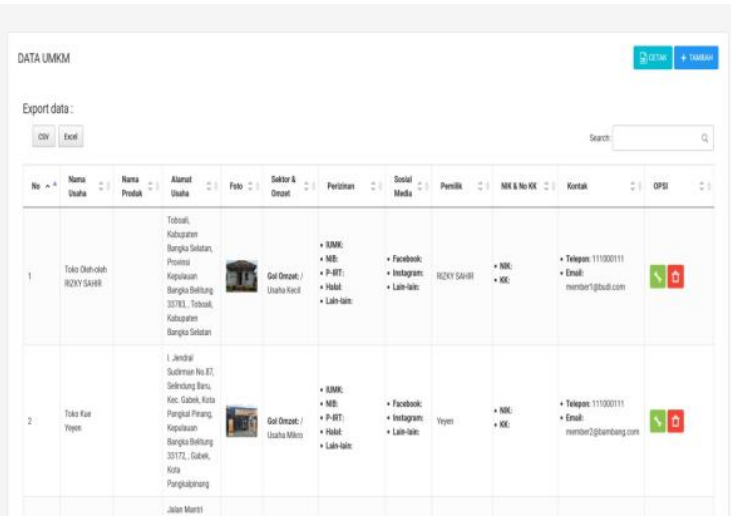

Gambar 24. Halaman Admin Data UMKM

Pada halaman tambah UMKM, admin akan disajikan formulir dengan beberapa isian yang harus ditambahkan. Jika telah selesai menambah data UMKM, klik tombol simpan (tombol biru). Pada contoh gambar di bawah, sebuah data UMKM baru ditambahkan melalui sisi admin.

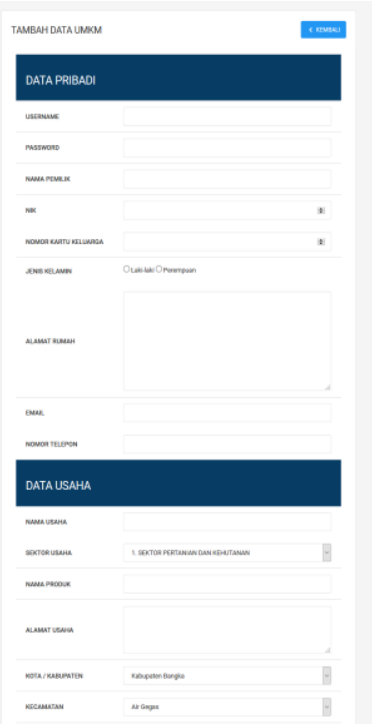

Gambar 25. Halaman Admin Tambah Data UMKM

\section{e. Halaman Admin: Cetak data UMKM}

Pada halaman Data UMKM, admin dapat mencetak rekap seluruh data UMKM. Ini adalah fitur tambahan yang tersedia di 
594 Sistem Informasi Aplikasi Pendataan (SIAP) UMKM Berbasis Kecamatan di Provinsi Kepulauan Bangka Belitung- Hilyah Magdalena, Hadi Santoso, Ade Septryanti

DOI: https://doi.org/10.31004/abdidas.v2i3.328

halaman Data UMKM. Cara untuk dapat mengaksesnya, klik pada icon "cetak" (warna biru muda). Perhatikan Gambar di bawah ini mengenai letak ikon cetak.

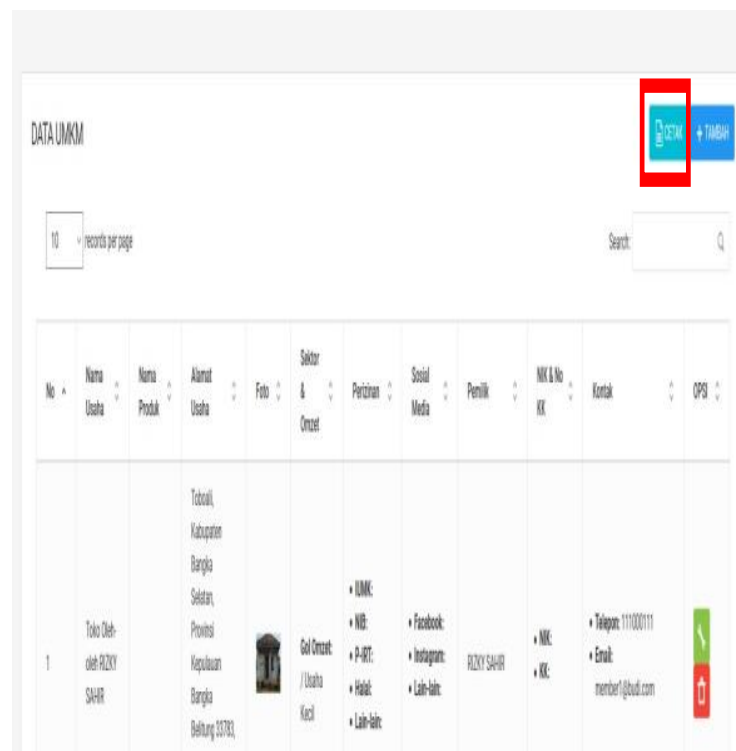

Gambar 26. Halaman Admin Cetak Data UMKM

Anda akan ditunjukkan sebuah halaman baru yang berisi tabel laporan data Usaha Mikro Kecil Menengah di Provinsi Kepulauan Bangka Belitung. Cara untuk mencetak dengan printer, klik tombol cetak (warna biru muda) yang terletak di tengah halaman. Gambar di bawah ini adalah halaman cetak laporan data UMKM.

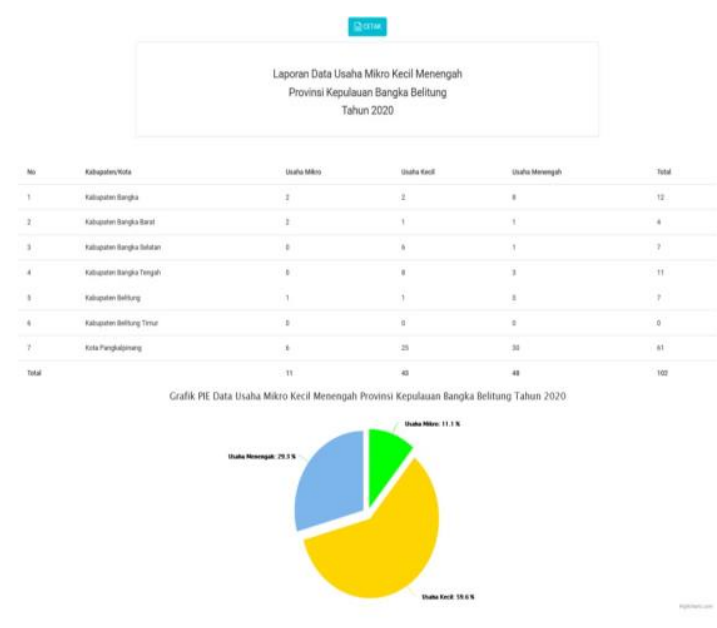

Gambar 27. Halaman Admin Tampilan Cetak Data UMKM

\section{f. Halaman Admin : Cari data UMKM}

Halaman Cari Data UMKM berisi form pencarian UMKM dengan parameter kabupaten/kota dan skala usaha. Cara untuk mencari data, masukkan isian di form yang tersedia dan klik cari. Cara untuk mencetak dengan printer, klik tombol Cetak (warna biru muda) yang terletak di pojok kanan atas. Gambar di bawah ini adalah halaman cari data UMKM

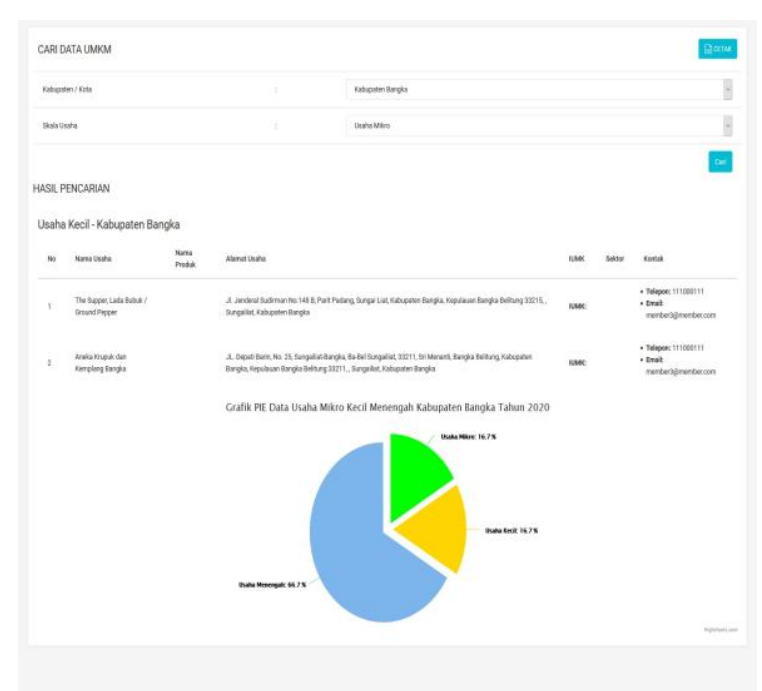

Gambar 28. Halaman Admin Cari Data UMKM 
595 Sistem Informasi Aplikasi Pendataan (SIAP) UMKM Berbasis Kecamatan di Provinsi Kepulauan Bangka Belitung- Hilyah Magdalena, Hadi Santoso, Ade Septryanti

DOI: https://doi.org/10.31004/abdidas.v2i3.328

\section{g. Halaman Admin: Logout}

Cara untuk keluar dari halaman admin, klik pada nama di pojok kanan bagian navigasi lalu pilih logout

Anda login sebagai : admin $\checkmark$

$$
\begin{aligned}
& \text { * Ganti Password } \\
& \text { (1) Logout }
\end{aligned}
$$

Gambar 29. Halaman Admin Logout

Berikut ini beberapa foto sesi Forum Group Discussion (FGD), dengan staf di lingkungan Dinas Koperasi dan UMKM Provinsi Kepulauan Bangka Belitung.

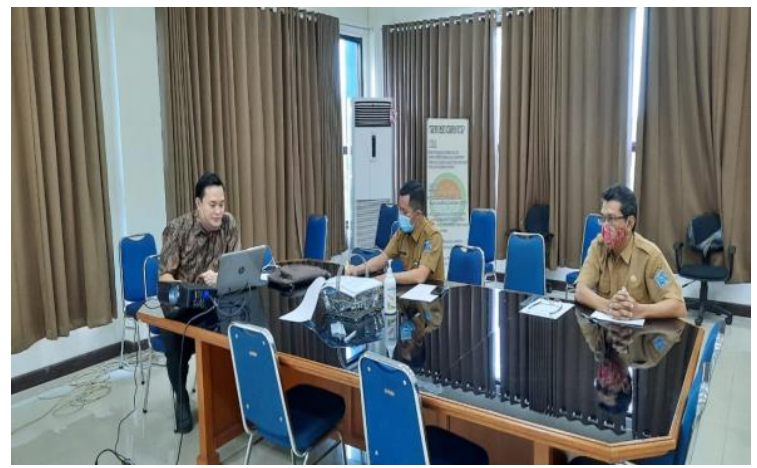

Gambar 30: FGD Survey Data UMKM

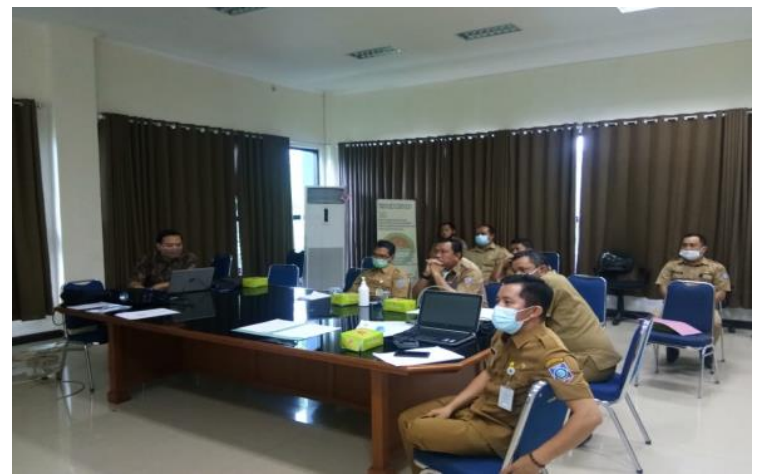

Gambar 31. Presentasi Prototype Aplikasi Pendataan UMKM Berdasarkan Nama dan Alamat Berbasis Web di Bangka Belitung

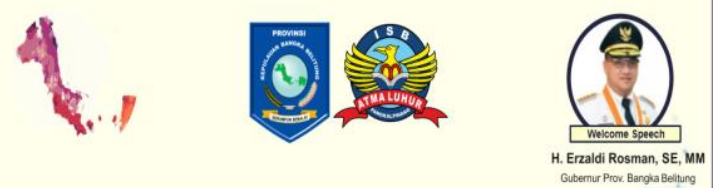

Bimtek Pandataan UNKM by Name by Address Berbasis Recamatan se-Provinsi Rep Bangka Belitung Tahun 2020

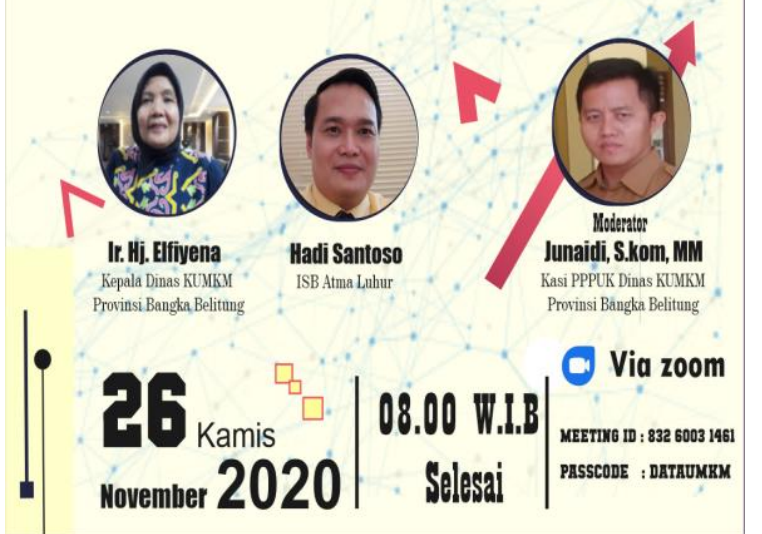

Gambar 31. Webinar Bimtek Pendataan UMKM

Kegiatan pengabdian masyarakat di Dinas Koperasi dan UMKM Provinsi Kepulauan Bangka Belitumg telah mampu menampung lebih dari 15 ribu data UMKM berbasis kecamatan. Ketercapaian ini menjadi dasar pengambilan keputusan penting bagi kemajuan UMKM di Bangka Belitung.

\section{SIMPULAN}

Kegiatan pengabdian kepada masyarakat yang kali ini bermitra dengan Dinas Koperasi dan UMKM Provinsi Kepulaian Bangka Belitung, telah mampu membantu mendata ulang pelaku UMKM di Bangka Belitung. Pendataan yang dilakukan berbasis web dan berbasis Sistem Informasi Geografis (SIG) memberikan hasil berupa akurasi data dan lokasi UMKM yang akurat. Data ini menjadi masukan berharga bagi Dinas Koperasi dan UMKM Provinsi Bangka 
Belitung juga menjadi sarana pendukung pengambilan keputusan untuk memajukan UMKM di Bangka Belitung terutama saat pandemik Covid-19 yang saat ini masih berlangsung. Kegiatan pengabdian masyarakat ini juga menjadi kesempatan bagi tim dosen dari Institut Sains dan Bisnis Atma Luhur untuk mengimplementasikan ilmu dan pengetahunnya di bidang teknologi informasi bagi kemajuan dan kemaslahatan masyarakat di Bangka Belitung dalam hal ini khususnya bagi pelaku UMKM.

\section{UCAPAN TERIMA KASIH}

Terima kasih kami kepada LPPM Institut Sains dan Bisnis Atma Luhur yang telah memfasilitasi kegiatan pengabdian masyarakat ini. Terima kasih juga kepada Dinas Koperasi dan UMKM Provinsi Kepulauan Bangka Belitung yang telah memberikan kesempatan melakukan Kegiatan Pengabdian Masyarakat tim dosen Atma Luhur, dan mengimplementasikan ilmu untuk berkontribusi positif dalam mendukung kemajuan UMKM di Provinsi Kepulauan Bangka Belitung.

\section{DAFTAR PUSTAKA}

Babel Hits. 2020. "Tahun 2021, Bangka Belitung Bakal Miliki Data UMKM Berbasis Kecamatan." https://kumparan.com/babelhits/tahun-2021bangka-belitung-bakal-miliki-data-umkmberbasis-kecamatan-1ufbHt045OX/full.

Dedy Setiawan dan Lutfi. 2018. "Analisis Dan Perancangan Sistem Informasi E-Commerce Berbasis Web Pada UMKM Batik Rindani Jambi." Jurnal Sains Sosio Humaniora 2: $227-49$.

Dennis, Alan, Barbara Haley Wixom, and David Tegarden. 2012. Systems Analysis and
Design with UML.

Dinas Kominfo. 2020. "UMKM Jadi Sumber Pertumbuhan Ekonomi Di Tengah Dampak Covid-19." https://babelprov.go.id/content/umkm-jadisumber-pertumbuhan-ekonomi-di-tengahdampak-covid-19.

Joel Sklar. 2015. Principles of Web Design. Sixth Edit. CENGAGE Learning.

Kemenkumham RI. 2019. Kemenkumham RI Peraturan Presiden Republik Indonesia No 39 Tahun 2019 Tentang Satu Data Indonesia.

Kominfo, Hasan A. M Dinas. 2020. "Satu Data UMKM, Pemprov. Babel Bimbing Integrasi Data UMKM." https://babelprov.go.id/content/satu-dataumkm-pemprov-babel-bimbing-integrasidata-umkm.

Nurcholik, Arif, Kartika Imam S, and Gatot Susilo. "Sistem Informasi Umkm Diskoperindag Kota Magelang." 13(1): 1-9.

Purba, Elvitrianim, Abdul Karim, and Sri Trianovie. 2019. "Sistem Informasi Pendataan Usaha Micro Kecil Dan Menengah Pada Dinas Umkm Labuhan Batu Berbasis Web." Jurnal Infotek 4(3): 1-8.

Rahimah Dinas Kominfo. 2020. "Melalui Digitalisasi, UMKM Babel Naik Kelas Dari Orientasi Lokal Menuju Pasar Ekspor." https://babelprov.go.id/content/melaluidigitalisasi-umkm-babel-naik-kelas-dariorientasi-lokal-menuju-pasar-ekspor.

Ramdhani, Gilar. 2020. "Percepat Digitalisasi UMKM, Dinas KUKM Babel Gandeng Marketplace Nasional." https://www.liputan6.com/news/read/442767 1/percepat-digitalisasi-umkm-dinas-kukmbabel-gandeng-marketplace-nasional.

Wulandari, Alvianis, Andy Prasetyo Utomo, and Fajar Nugraha. 2016. "Pemetaan Industri Kecil Dan Menengah (IKM) Menggunakan Sistem Informasi Geografis (SIG) Berbasis Web Di Kabupaten Kudus." In Prosiding SNATIF, 323-28. https://jurnal.umk.ac.id/index.php/SNA/articl e/view/666/678. 